\title{
Conflict on the Northern Front: Archaeological Perspectives on the Spanish Civil War at Monte Bernorio, Palencia, Spain
}

\author{
Jesús F. Torres-Martínez ${ }^{1}$ • Manuel Fernández-Götz ${ }^{2}$ (D) \\ Alicia Hernández-Tórtoles ${ }^{3}$ - Antxoka Martínez-Velasco ${ }^{4}$
}

Published online: 11 August 2020

(C) The Author(s) 2020

\begin{abstract}
The archaeology of the Spanish Civil War (1936-39) has experienced an important development over the last two decades. Several field projects have studied aspects such as mass graves, forced labor camps, and battlefields. In this paper, we present a case study from the so-called "Northern Front" (Frente Norte). The impressive mountain of Monte Bernorio, situated at the foothills of the Cantabrian Mountains, controls one of the main communication routes between the central Spanish plateau (Meseta) and the Cantabrian Sea. Due to this strategic position, the site has played an important military role during two episodes of war separated by nearly 2,000 years: the Roman conquest of northern Iberia under Emperor Augustus in the 20s BCE, and the Spanish Civil War in the years 1936-37. The ongoing archaeological excavations and surveys are uncovering abundant remains of trenches, battering positions, barracks, and munitions belonging to the Civil War period, when Bernorio was a highly disputed position in the confrontation between "Republicans" and "Nationalists." Adopting an interdisciplinary approach, this paper combines archaeological evidence, oral history, and written documents that shed light on one of the main episodes of Franco's conquest of northern Spain.
\end{abstract}

Key Words Spanish Civil War $\cdot$ Frente Norte $\cdot$ Monte Bernorio $\cdot$ Fortifications $\cdot$ Spain

Manuel Fernández-Götz

M.Fernandez-Gotz@ed.ac.uk

1 Instituto Monte Bernorio de Estudios de la Antigüedad del Cantábrico (IMBEAC) \& Universidad, Complutense de Madrid, Madrid, Spain

2 School of History, Classics and Archaeology, University of Edinburgh, Teviot Place, EH8 9AG Edinburgh, United Kingdom

3 Universidad de Cádiz, Cádiz, Spain

4 Sociedad de Ciencias Aranzadi, Sección de Arqueología Prehistórica, San Sebastián, Spain 


\section{Introduction: Archaeology of the Spanish Civil War at Monte Bernorio}

The Spanish Civil War (1936-1939) is among the armed conflicts of the twentieth century that has attracted interest by both scholars and the general public (e.g., Beevor 2006; Graham 2005; Payne 2012). Often seen as a forerunner of, or test laboratory for, World War II, its scars are still deeply present in Spanish society. This is perhaps best exemplified by the recent controversy surrounding the exhumation of General Franco's remains from the "Valle de los Caídos" ("Valley of the Fallen"), an impressive monument erected by the regime to commemorate its victory and serve as the last resting place for the dictator.

While there is a long and prolific tradition of historical studies about the Spanish Civil, the archaeological investigation of the conflict and its afermath is much more recent. However, the last two decades have witnessed a boost in archaeological research on the war, including numerous fieldwork projects (often organized as the result of bottom-up initiatives), conferences, and publications. Archaeological excavations have multiplied at the different sites in which this conflict played out, including battlefields, mass graves, forced-labor camps, and commemorative monuments (see the overviews in González-Ruibal 2008, 2012, 2016, 2020; Pérez-Juez Gil and Morín de Pablos 2020).

As part of this line of research, the present article analyzes, from an interdisciplinary perspective, the remains of the Spanish Civil War encountered at Monte Bernorio in Palencia province, northern Spain. This site has a great potential for the study of conflict archaeology, as it was a battlefield at two very important historical moments almost 2,000 years apart: the Roman conquest by Emperor Augustus' troops during the Cantabrian Wars (29-19 BCE) and the military operations on what was known as the "Northern Front" (Frente Norte) during the Spanish Civil War (1936-37). At the end of the 1st millennium BCE, Monte Bernorio was an important fortified town (oppidum) of the Cantabrians, until it was destroyed by the Roman legions. The results of the archaeological research corresponding to the Roman conquest have been published elsewhere (see Fernández-Götz et al. 2018; Torres-Martínez 2015; Torres-Martínez et al. 2016), including the application of analytical tools such as the KOCOA analysis (Brown et al. 2017). In the present article we will therefore concentrate on the evidence from the Spanish Civil War, which remains largely unpublished and is presented here for the first time to an international audience.

The impressive Monte Bernorio mountain $(1,173 \mathrm{~m})$ is on the southern slopes of the Cantabrian range, in the eastern zone of the so-called "Montaña Palentina" (Fig. 1). Its summit offers a view of a vast area that includes the basins of the River Pisuerga, and access to the Upper Ebro Valley, the Sierra Hijar and the Sierra de Peña Labra, as well as the passes to the Campoo and La Pernía counties. Thus, it controlled various natural communications routes, including the south-north route that connects the Spanish Meseta or Inner Plateau with the Cantabrian Sea. This strategic geographical position explains the importance of Monte Bernorio both during the Cantabrian Wars in the 1st century BCE and the Spanish Civil War in the twentieth century. The Iron Age oppidum occupied the summit and slopes of a limestone hill with a relatively flat top, covering an area of ca. 28 has, which were enclosed by a wall and ditch. In addition, some outer linear earthworks extended the enclosed area to a total of ca. 90 ha (Torres-Martínez et al. 2016). 


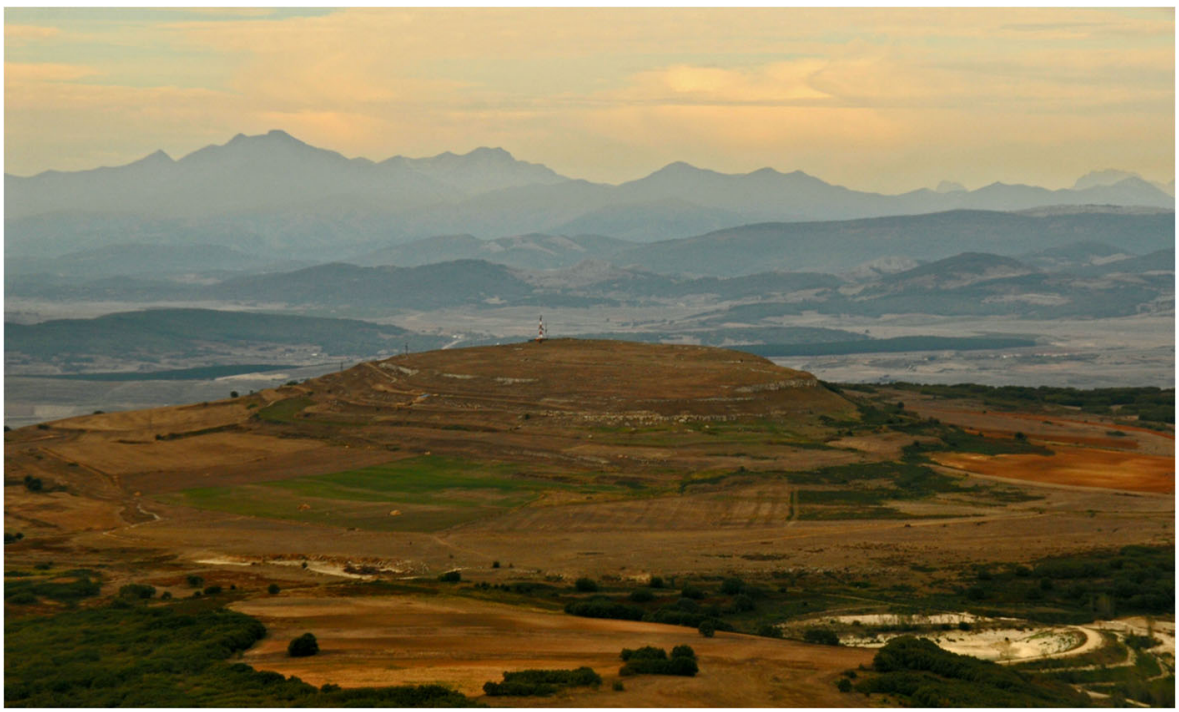

Fig. 1. The Bernorio Mountain, in the background the Cantabrian Mountains (IMBEAC. Photo: D. Vacas, modified by A. Martínez-Velasco).

The site was first excavated in 1890 by Romualdo Moro, who was commissioned by the Marquess of Comillas to undertake archaeological investigations in order to discover objects for his private collection. The metal finds, particularly 1 st millennium BCE daggers of the so-called Monte Bernorio type, were studied by some of the most important late-prehistory researchers of the time. Therefore, when the Spanish Civil War broke out in July 1936, it was already a well-known archaeological site. Due to its strategic position, it was initially occupied by forces loyal to the Republic (Republican army, republicanos) and was probably cursorily fortified to prevent it being taken by the militia and army forces of General Franco (Nationalist army, nacionales) before the so-called Northern Front was established. Despite these efforts, the position was soon assaulted and taken by the Nationalists, who fortified it and strengthened the defences to prevent it falling back into Republican hands. From then on the Republicans made continuous attempts to retake the enclave until the Nationalist troops finally broke through the Northern Front line in the summer of 1937. The fortification works and combat seriously affected the prehistoric archaeological remains, since the Iron Age structures -for example the remains of the defensive wall- were often reused and/or dug up during the Civil War. In fact, when excavating the site, we constantly find items from both periods together.

After the Civil War, the archaeologist J. San Valero Aparisi undertook three excavation campaigns (1943, 1944, and 1959). In 1992 the archaeological site was declared an Asset of Cultural Interest in the Archaeological Zone category. Finally, in 2004 new archaeological work began as part of the current "Monte Bernorio in its environment" research project, directed by the IMBEAC (Monte Bernorio Institute of Ancient Studies of the Cantabric) and since 2015 with the collaboration of the University of Edinburgh.

Methodologically, the archaeological investigations carried out since 2004 have been focused on field surveys for documenting artifacts and structures, combined with 
some small-scale targeted excavations and the information provided by ultralight flights. Due to administrative restrictions, the use of metal detector surveys has been limited. In 2013-14, a topographic map with all the identified structures of the Spanish Civil War was created. Since 2012, the results of the archaeological investigations have been enriched by a number of publications that address the military operations in the region on the basis of written sources (Román Ibáñez 2013; Ruiz Alonso 2012), in some cases combined with the oral testimonies of war veterans (Román Ibáñez 2015, 2017). While these works contain rather limited information on the material remains of the war, they provide important historical context for the development of the military events and offer insights into the living conditions of the soldiers stationed on the mountain. The archaeological investigations do not contradict the information from the written sources, but rather are complementary in the sense that they offer valuable data which are absent from the historical accounts.

\section{Monte Bernorio as Part of the Northern Front: A Brief Historical Overview}

At the beginning of the Civil War in the north of Palencia, the rebel soldiers that formed the Nationalist troops and the militias that sympathized with them were at a numeric disadvantage against the troops and militias loyal to the democratically elected Republican goverment (see Román Ibáñez 2013, 2015, 2017; Ruiz Alonso 2012). Despite this, the Republican institutions failed to understand the situation correctly and exploit it in their favor. They lost all the towns in the mining basin, where groups of tradeunionist miners loyal to the Republic were initally in the majority, and the Republican forces retreated to fortified positions in the mountains and to the town of Reinosa in southern Cantabria. The main heights of the Sierra Hijar and those that overlooked the Santullán Valley were mostly in Republican hands, although part of them, those that overlooked Barruelo de Santullán, were taken by the Nationalists. Nevertheless, Monte Bernorio, despite its obvious strategic value, does not appear to have attracted the attention of either side in these initial stages of the conflict (Román Ibáñez 2015: 106136, 166-248).

However, this situation changed on October 10, 1936, when the Republican forces launched an offensive during which they occupied Monte Bernorio (Román Ibáñez 2015: 291-299). Despite its strategic importance, its occupation and defense were left in the hands of the Malumbres battalion, a poorly trained group of soldiers with no combat experience. In a counter-offensive, the Nationalists finally understood the value of this position and began their attack at midnight on October 16, taking Monte Bernorio in the morning. After that, the Republicans launched an intense counterattack, managing to reoccupy part of the northern slope of the mountain. However, they were unable to dislodge the Nationalists and finally decided to withdraw to more secure positions facing the northern side of the mountain (Román Ibáñez 2013: 94-110, 2015: 299-320; Ruiz Alonso 2012: 56-65). Thus, Monte Bernorio became a key point in the articulation of the line of Nationalist troops, as they were able to guarantee the northern frontline from that position. It remained a disputed position until late 1937, but the Republican attempts to reconquer the mountain remained unsuccessful. 


\section{The Building of the Fortifications (1936-37)}

To prevent Monte Bernorio falling back into Republican hands, the Nationalists fortified the position, a task severely hindered by Republican aircraft, artillery, and infantry attacks, which caused considerable casualties. For this reason, they put a great deal of effort into building fortifications on the summit. The plan to take Monte Bernorio included fortifying it quickly and holding it at all costs. The battle plan established that two of the lorries from the convoy would be used to fortify the summit and that reinforcements would help consolidate the positions (Ruiz Alonso 2012: 62).

For their part, the Republicans also consolidated and fortified their line of positions. The Republican and Nationalist areas were separated by barely $600 \mathrm{~m}$ and exchanges of fire were frequent. To guarantee a transportation route to the Nationalist positions on Monte Bernorio, a dirt track was built from the village of Villarén to the top of the mountain with the help of residents from the surrounding towns and villages. This road was used to bring in supplies and reinforcements and to provide communications for the position via a telephone line that was installed until Villarén (Román Ibáñez 2013: 94-110, 2015: 299-320; Ruiz Alonso 2012: 65).

The construction of the defenses was very difficult, as the Republicans had not resigned themselves to losing Monte Bernorio and continually attacked the Nationalist troops who put all their efforts into defending the position during the day and digging trenches and shelters at night under the cover of darkness. Casualties were constant and numerous. Monte Bernorio was a heavily castigated position and the relief of its summit provided no shelter from the constant fire of the Republican riflemen or the artillery and aircraft attacks. This made the construction of all types of protective structures and semi-subterranean shelters a matter of prime importance.

Moreover, one of the most outstanding features of the Monte Bernorio position was its use as an observation point over the front line and for correcting the artillery fire from the batteries set up in El Castillejo and El Moral. The visual domination from the summit of Monte Bernorio allowed excellent control of the territory and a special position was prepared for that purpose. The strategic importance of Monte Bernorio during the war is best exemplified by the visits made by some of the leading figures of the Supreme Command of the Nationalist army, including General F. Dávila (Commander-in-Chief of the Northern Army) and General F. Franco himself (Commanderin-Chief of the Nationalist Army) (Román Ibáñez 2017: 327-329; Ruiz Alonso 2012: 65).

The medium- and high-altitude aerial photographs of the northern slope of Monte Bernorio, which were taken within the framework of recent research, have identified a dense system of Civil War trenches and fortified positions that protected the summit from west to east behind the steep slopes and the line of the Iron Age wall. Most of the preserved positions are in the northern sector of the summit, inside the ancient Iron Age oppidum, and were set up by the Nationalist forces. On the contrary, in the areas both on the summit and slopes of Monte Bernorio that were in agricultural use after the Civil War the remains of trenches and fortification works were largely obliterated, and their precise positions are no longer known.

Based on the archaeological field and aerial surveys of the construction remains from that time and the historical documentation currently available, the defences of Monte Bernorio during the Civil War were organized as follows (Fig. 2): 


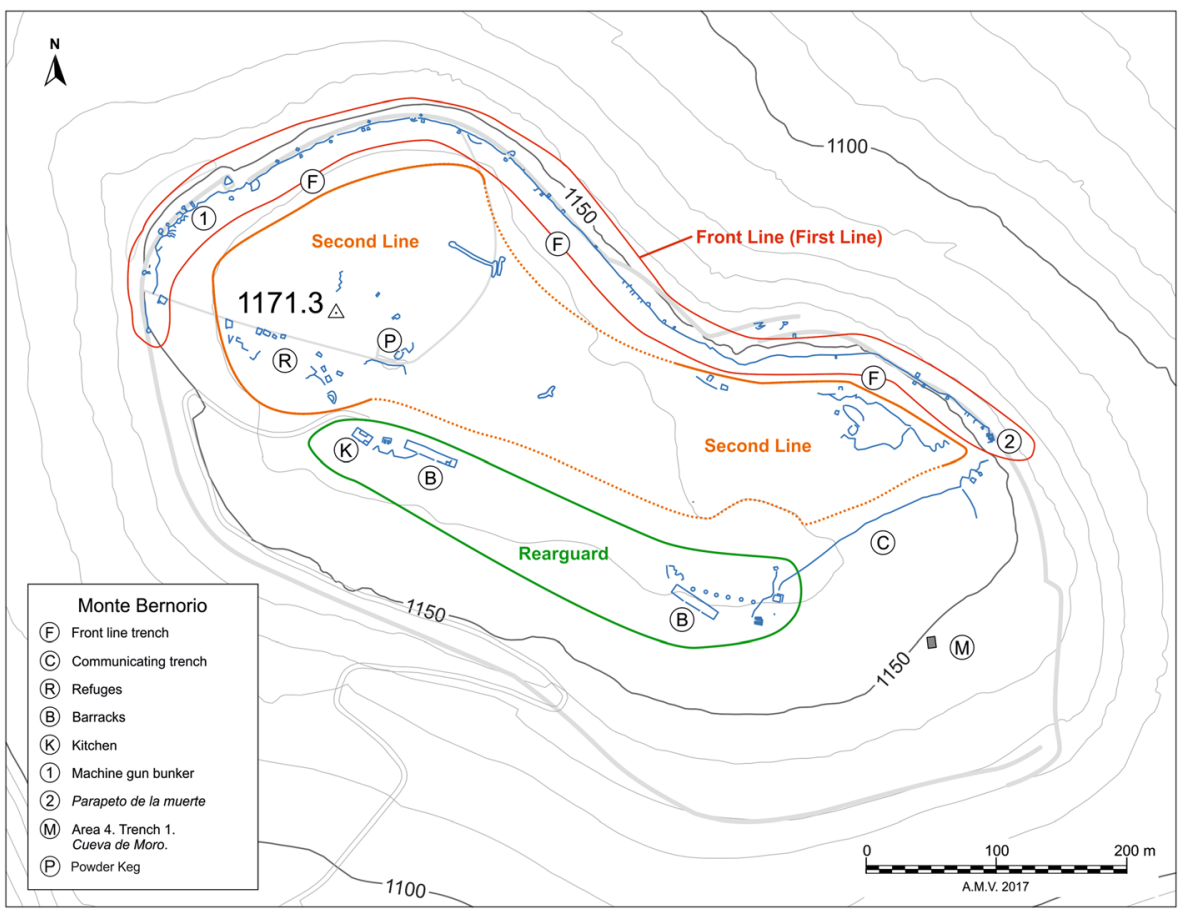

Fig. 2. Plan showing the general layout of the defensive lines and the fortifications built at Monte Bernorio during the Spanish Civil War (1936-37) (IMBEAC. Topographic data D. Sergio Rodríguez Muñoz; design by A. Martínez-Velasco and M. Galeano).

\section{First line of trenches}

This line of trenches runs along the northern side of the summit from north-west to south-east, taking advantage of the layout and structure of the remains of the Iron Age oppidum wall, which became the exterior face of the trench line. This line had a masonry bunker at each end, rifle positions, other larger pits (probably for a machine gunner and loader) and shelters for protection against air attack. It had a linear layout as it was protected by the interior face of the wall, but had a zigzag section to avoid the "sweeping" effect of machine gun attacks from the air and to reduce the shockwaves from shells or bombs exploding in it.

Regarding life in the trenches, W. Román Ibáñez offers us the testimony of E. García from the village of Nestar: "During the day we spent the whole time in the trench, silent and without moving. Each soldier was separated from the next by four or five metres, so there was practically no talk or anything. If anybody stuck their head up, they were fired at straight away". The same author also quotes P. Regalado Prieto, a soldier from the Villarobledo Regiment who fought at Monte Bernorio: "In the trenches we had picks and shovels and if you raised a shovel above the edge of the trench they riddled it with bullets" (Román Ibáñez 2013: 114, 2015: 312).

The trenches were probably reinforced with posts and planking, using stones and sandbags in order to maintain a suitable depth (or height above the ground) to protect the riflemen and the men moving about the trench. On some parts of the slope it was 
not possible to dig very deep into the earth and protection was achieved by piling up sandbags and/or building low stone walls. At favorable points along the line, irregularly spaced shelters were built so that the soldiers could protect their belongings, ammunition, and themselves in the case of an aerial attack or artillery bombardment. These shelters were rectangular clefts dug into the ground and covered with planking, sandbags, soil, plant matter, and stones. The soldiers would have had to have crawled into them and stayed lying down. The trenches were also protected by barbed wire stretched between wooden posts and, in some cases, metal posts.

The bunkers were built of stone obtained from stripping the Iron Age wall and laid with cement mortar. They built two different types of bunkers with these materials, one on the western side and the other on the eastern side. On the western side of Monte Bernorio we found an elongated rectangular-type bunker, with its narrowest sides facing the interior and exterior of the defensive line. Toward the exterior side it was embedded in the Iron Age wall to reinforce it. At this point there is a horizontal, rectangular loophole; it is open at the ends practically at the same width as the construction itself. It did not have a masonry roof and was covered with planking and perhaps corrugated iron or cement fiber sheets, sandbags, stone, soil, and turf. Inside there was just about enough room for a machine gunner and his loader or a machine gun on a tripod with its respective loaders and ammunition. The exit connected with the frontline trench system. This bunker was opposite one of the strong points of the Republican defensive lines.

On the eastern side of Monte Bernorio there is a rectangular bunker with an unusual spiral-shaped ground plan that was known as "the parapet of death" (parapeto de la muerte) (Fig. 3). It is on the edge of the summit in an area where the slope is precipitous and has a long drop. This did not make it immune to enemy fire and it was very exposed to the Republican snipers. Its construction claimed many casualties, as it is attested that Republican bullets killed and wounded many soldiers in that spot (García Guinea 2005: 42-46; Román Ibáñez 2013: 111-113, 2015: 307-309). The bunker did not have a masonry roof but was covered with a structure of planking and perhaps a corrugated iron or fiber cement roof covered with sandbags, stone, and earth. Its peculiar shape was designed to protect the interior of the structure from explosive shockwaves, but that also meant it was very small inside. The exit connected to its own system of trenches to defend the position, which in turn was connected to the frontline trenches and the auxiliary trenches that led to the second line. This bunker was also built opposite one of the strong points on the Republican defensive lines.

\section{Second line of trenches and service trenches}

Running from each end of the first line of trenches were the "service trench" lines. These connected to a "second line of trenches" for the rear defense of the position. On the western side it is still possible to make out the remains of this intricate line of trenches with a large number of shelters and small refuges (the so-called "chabolos" or "chamizos") (Fig. 4).

Of particular note in the easternmost area of this sector is the system of trenches and small refuges that were dug inside the so-called Castillejo ("small castle"), the base of a tower situated within the enclosure of the Roman castellum (fort) that was erected on the highest point of Monte Bernorio after the destruction of the indigenous oppidum by 

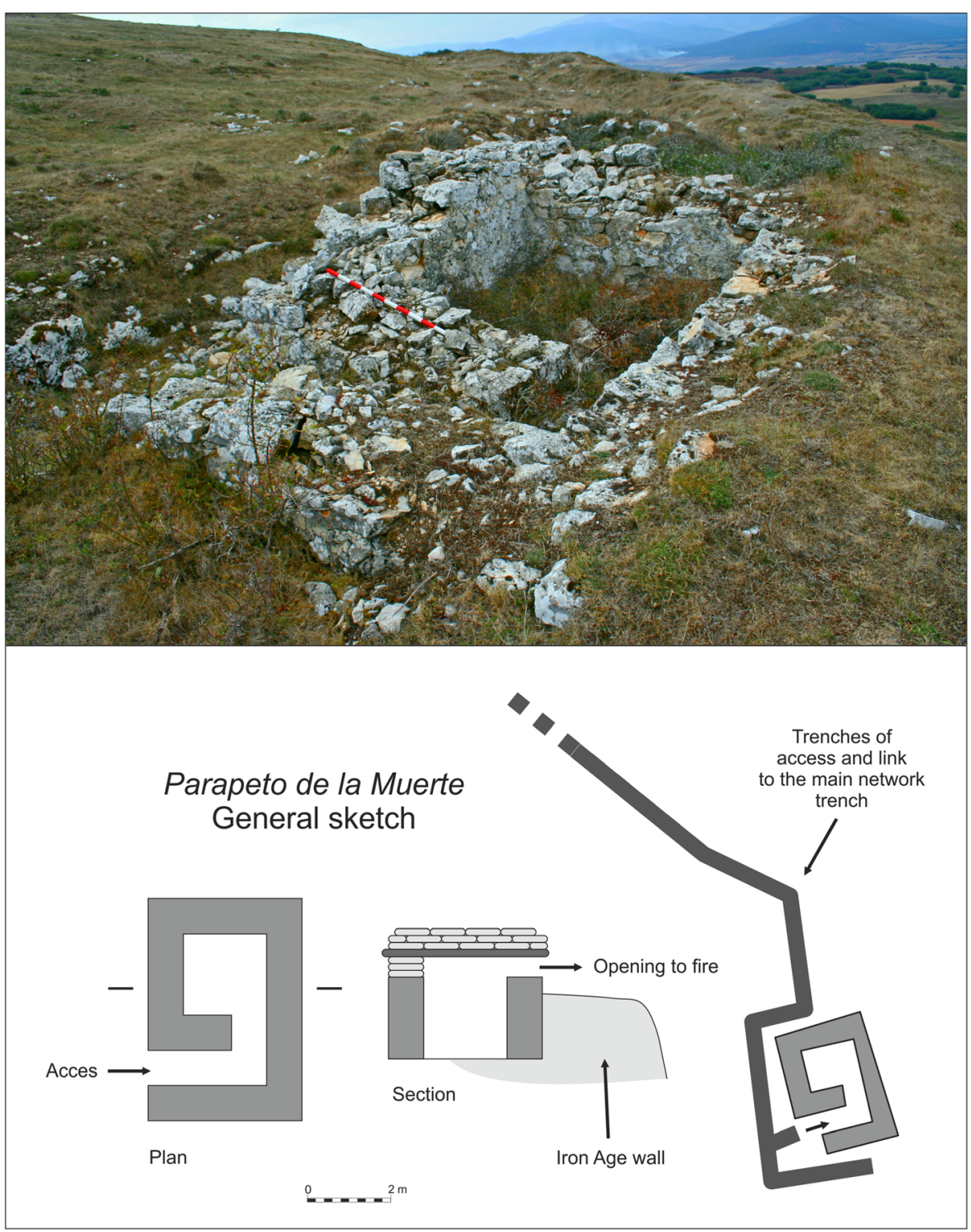

Fig. 3. Above general view of the remains of the "Parapet of Death" bunker and below a sketch of that fortification (IMBEAC. Drawing: A. Martínez-Velasco).

the Roman legions. This tower was built on a base of dry-laid ashlars and was partially emptied inside to dig a central shelter, various rifle pits, and service trench lines, all by emptying out the stonework of the Roman structure.

The oral informants who collaborated in our study said that the shelter was used to store the ammunition and hand grenades to be used by the frontline troops, with the solid stone structure providing greater protection. Nevertheless, a Republican shell penetrated it and exploded inside, causing the estimated 11,000 rifle cartridges and hand grenades to explode, resulting in a large number of casualties. 


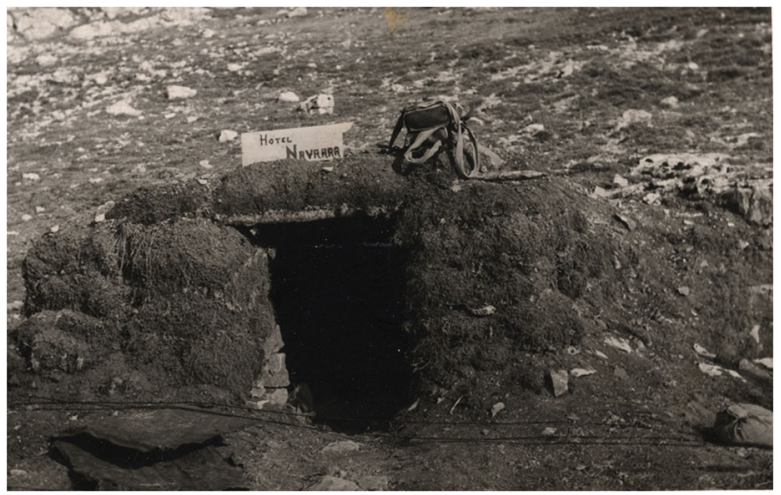

Fig. 4. Photograph from 1937 showing a small shelter built of stone and wood and covered with turf, probably on the western side of Monte Bernorio, in the second defensive lines. Both the type of shelter and the poster with a humorous tone recall similar structures built by soldiers in the First World War. At the bottom there is a line of cables, probably telephone lines (photo ceded by W. Román).

The eastern end of the second defensive line was built in a similar way to the first line, with rifle pits, shelters for the soldiers, and semi-subterranean positions that were larger than the shelters. These positions would have acted as small strong points, in that they could probably have held a machine gunner and his feeder, as well as various snipers. They were also used to store ammunition and as a communications hub for the trench network.

\section{Living structures for the troops}

Nearer the southern side, on the edge of the summit and at the beginning of the southern slope of Monte Bernorio, was the "rearguard line." This line was connected to the second line of trenches by the "service trench" lines. Its accesses were probably also protected by barbed wire. The rearguard was where the troop shelters, stores, kitchens, and latrines were found.

On the western side, in the area where the track up to the summit ended, was the socalled kitchen, with its store, some shelters and small refuges, latrines, and a large shelter. These were all semi-subterranean constructions that were connected by a network of service trenches. They were built of stone, wooden posts, and sandbags and had cement-fiber sheet roofing covered with soil, stones, and more sandbags. They had several entrances and exits to the various trench lines and a brick hearth that served both as a stove and a heater.

The kitchen was a quadrangular-shaped, semi-subterranean shelter with a hearth built of thick refractory bricks on a concrete slab in the eastern corner. It had the remains of the foundations of internal structures or rooms, probably larders and food safes. This is where hot food was served to the troops and we know from the testimony of L. García Guinea (2005: 46) that the soldiers would have queued up outside this building to receive their rations. This would have exposed them to the cold, wind, and rain, as well as stray bullets, artillery barrages, and aircraft attacks. The testimony of witnesses recorded by Román Ibáñez (2013: 114-115) state the following: "at night ... 
[they didn't eat] anything most of the time because you had to queue up outside the kitchen, in the open, and it was so cold that we preferred to continue sleeping rather than waiting half an hour to eat a plate of beans."

Near the kitchen are the ruins of part of a quadrangular-shaped building that was used as a store and latrines. The latrines can be distinguished by their specific shape: two parallel pits covered by planks on which soldiers squatted to defecate, either into metal cauldrons or straight onto the ground. They were delimited and superficially protected by stones, and probably also by sandbags and planking. The faeces subsequently dissolved or were burned using chemical products or removed and buried elsewhere.

The troop shelter, one of the two large shelters in the rearguard of Monte Bernorio, had an elongated rectangular ground plan, several exits, and a small room (a small store or woodshed) built up against its eastern side. The shelter was dug into the slope on its longitudinal axis and it is there where the transversal beams that held the roof were supported. These beams were also supported by posts on medium-sized stones that, in many cases, are still in situ and standing upright. The roof could not have been very high, as the witnesses tell us that it was difficult for a man of normal height (in 1936) to stand upright. The roof was mainly made of fiber-cement sheets, of which some fragments can be seen around the remains of the structure, and perhaps some corrugated iron sheeting and very few tiles, of which there are also some fragments. It would have been held up and/or covered by sandbags and perhaps turf and stones. The exterior walls (those not supported by the slope) were built of dry-stone blocks and the walls and floor were covered with wooden planks. There was a stove or a fire on refractory bricks.

On the eastern side of Monte Bernorio there was another large troop shelter with latrines, as well as a series of rifle pits to defend the position in case the enemy managed to break through the first and the second trench lines (Fig. 5). The shelter was built in a similar way to that of the western side, but the slope still preserves a ditch used to drain the waters and the lowering of the ground into which the roof was inserted and supported. It had three entrances and it preserves the remains of at least one fireplace as well as various supports for the vertical beams that held up the roof.

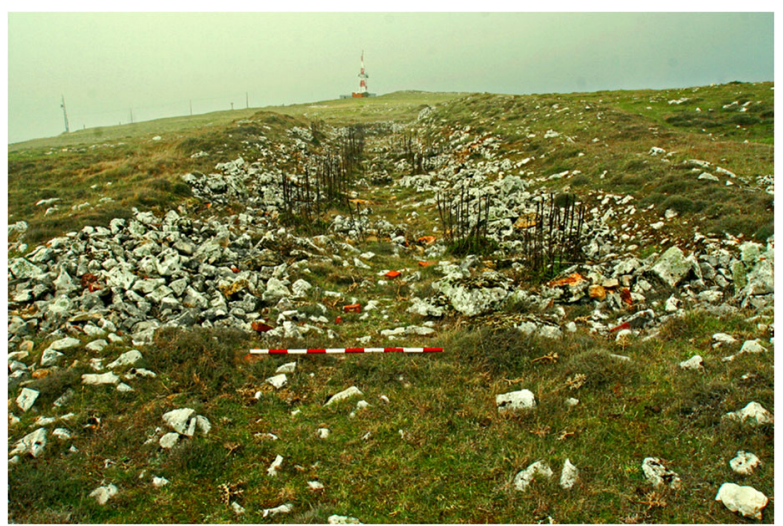

Fig. 5. Photograph of the large troop shelter located on the eastern side of Monte Bernorio (IMBEAC). 
It was in these shelters that most of the Nationalist troops posted to Monte Bernorio slept at night; their numbers ranged from 160 to 300 (Román Ibáñez 2013: 115). Oral accounts describe the inside of these shelters as very gloomy, almost dark, a sensation added to by the smoke from the hearths: "At first you can't see anything but a fire on the floor and various soldiers around you. [ ...] You can't stand up because the ceiling isn't high enough. And it leaks like a sieve! [...] And the night? In the chabola (shack), frozen to the bone, you don't feel like talking and you don't get a wink of sleep. [...] and the "shacks" where we slept... something like dark stables with straw on the hard ground for a bed." This testimony refers to the month of November 1936; it had already
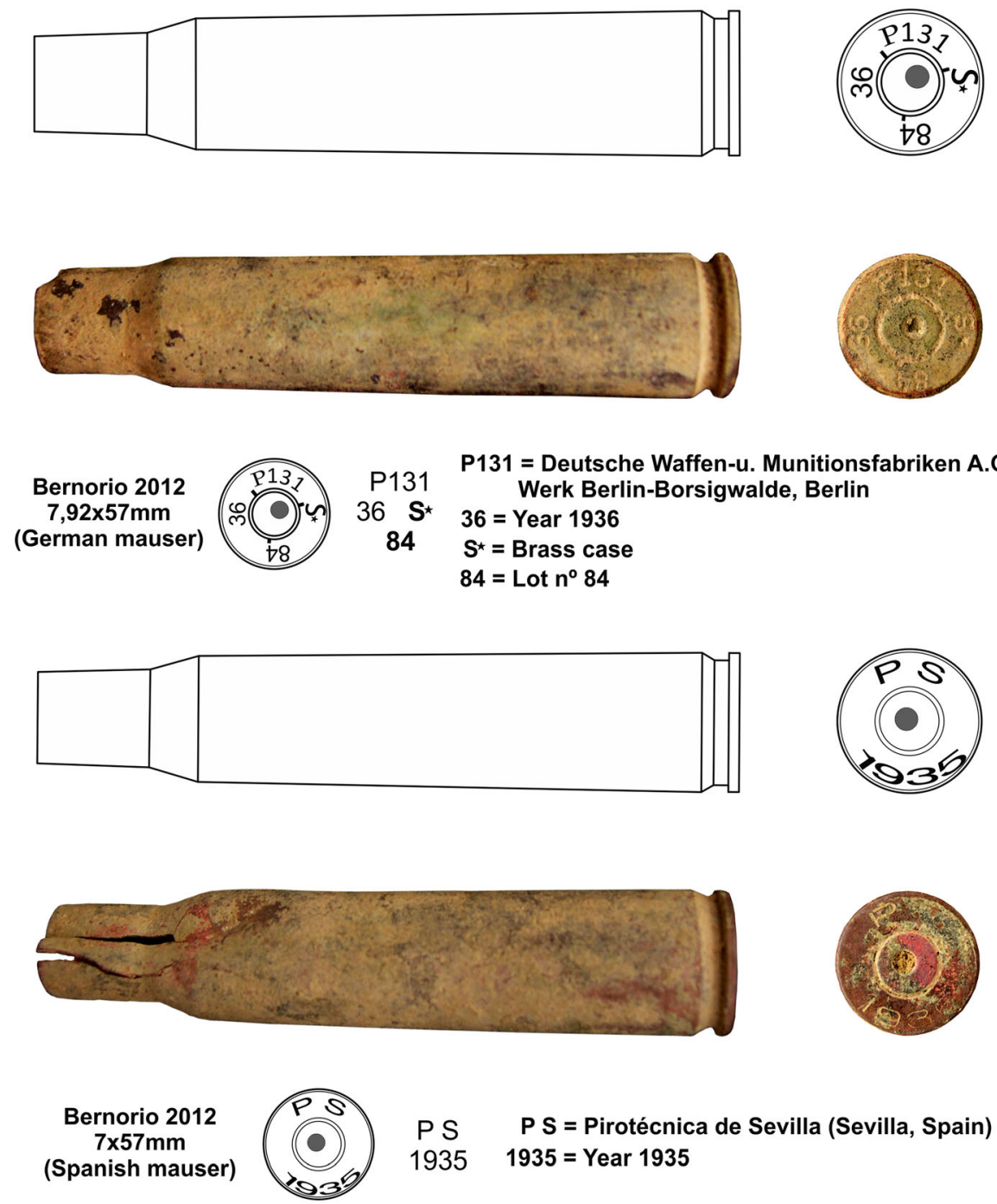

A.M.V. 2012

Fig. 6. Two of the spent cartridges found at Monte Bernorio (IMBEAC. Design A. Martínez-Velasco). 
snowed in the county and the summit of Monte Bernorio was covered in snow (Román Ibáñez 2013: 111-112, 2015: 307-314).

Next to this large shelter there was a natural cliff area that was cursorily fortified and traditionally called the "place of the officers." This was the location of the observation post and from where artillery fire was corrected using periscopes and binoculars that were well situated in a defiladed position (Román Ibáñez 2017: 325).

There are also some traces of rifle positions on the eastern and southern sides of Monte Bernorio. These are less important, but interesting, as they could be part of the ephemeral Republican defensive layout. In what we call Area 4, in the southeastern zone of Monte Bernorio, we excavated a natural cleft (trench 1) with a surface occupation level from the Civil War (see Fig. 2: M). On this level we found evidence of military engagement, including some cartridge cases for Spanish Mauser-type rifles (7 x $57 \mathrm{~mm}$ ) and various spring loaders (Fig. 6), which attested to an exchange of fire. In addition, we recovered the firing pin from a Lafitte-type hand grenade and the wing of an Adrian-type helmet ripped off by the impact of a shot and a with bullet hole with a downward trajectory.

In 2017, the test trench on the southern terrace (Area 3) was expanded, uncovering a rifle position with a small access trench. This structure was cleaned and is pending further excavation and documentation in future campaigns. To date, the only confirmed remains of the Republican occupation are a semi-subterranean shelter with a rectangular ground plan dug into the northern slope of Monte Bernorio. Its general features are identical to those of the Nationalist shelters.

\section{The Ammunition Evidence}

In addition to the aforementioned defensive systems and the infrastructure for storage, living, and connecting the different positions, different types of transportable materials have been identified thanks to intensive surveying work and archaeological excavations. Varying types of remains have been documented. As is to be expected, the greatest volume of military items is in the form of rifle ammunition: spring loaders or loaders for Mauser-type bolt-action rifles, shell cases and projectiles (bullets), shrapnel from defensive and offensive hand grenades (especially of the Laffite-type), and shrapnel from artillery shells and aircraft bombs (for information on the armament used by both political sides during the Civil War, see Manrique and Molina 2006; Valenciaga 2007).

Of particular interest for the study of the arms used and the origin of the supplies is the information provided by the cartridges. Despite the variety of armaments used, the most frequently found type is the 7 x $57 \mathrm{~mm}$, used for the Spanish Mauser-system rifles. The main munitions supply factories were the Pirotécnica in Seville and the Fábrica Nacional in Toledo. The next most frequently found cartridge is the $7.92 \mathrm{x}$ $57 \mathrm{~mm}$ for the German Mauser, where we have a wider variety, mainly from German factories bearing the so-called "P Code" marking. These were exported directly by the Nazi government to support the Nationalist cause. Other German productions (or those made on behalf of Germany) were sent as contraband and received by both sides; they were also $7.92 \times 57 \mathrm{~mm}$ caliber and marked with just a $\mathrm{W}$. 
Finally, we have also documented a $8 \times 50 \mathrm{~mm}$ casing for Lebel-type rifles of French origin. It had First World War markings, which was particularly interesting as it is very possible that it was part of the union material used in the 1934 miners' revolutionary uprising that had been kept since that episode.

This repertory of cartridges tells us of the predominance of the Spanish Mauser-type rifles, with a clear presence of German arms on both the Republican and the Nationalist sides, in keeping with the development of the conflict in its first phase. Although the recovered evidence is likely only an infinitely small part of what was actually used, the information provided is nonetheless representative. This is exemplified by the remains of the armament used by the Nationalists, logically the most abundant since they occupied the positions on Monte Bernorio for the longest time.

Complementing the remains of ammunition, other elements of armaments have been identified, for example the remains of shrapnel scattered across the length and breadth of Monte Bernorio. It is found mainly near the numerous bomb and artillery shell craters. With respect to the grenades, we have recovered at least two safety rings. One of them, a fragment of Laffite grenade ring, and two fragments of the trigger device from the same artifact, were found during the 2016 excavation campaign in Area 4, in the trench known as "Cueva de Moro." From the results of the excavation, it appears that an exchange of fire took place here. In that context, the ring would have come from a grenade thrown inside during the assault on the position.

\section{Small Objects Tell Everyday Life Stories}

Finally, we cannot forget the small finds that tell us about aspects of daily life, such as the food and drink consumed by the Civil War occupants of the site. Most of the evidence comes in the form of tins that mainly contained sardines and peppers, as well as some of meat, condensed milk, and other processed foods (Fig. 7). According to the testimonies collected from ex-combatants, this made up their basic diet. The foodstuffs were handed out with bread when combat conditions meant that only cold rations could be distributed, along with a drink (water and occasionally wine or another alcoholic

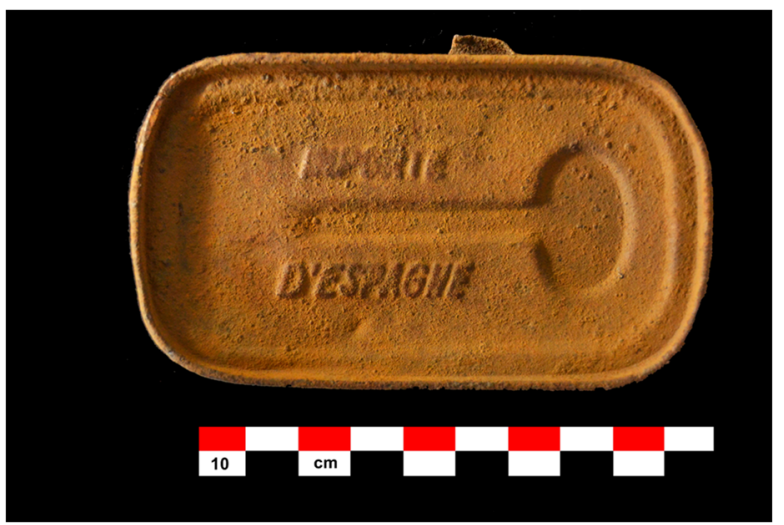

Fig. 7. Sardine tin with the inscription "Importe d'Espagne" (imported from Spain written in French) (IMBEAC). 
drink). The hot rations consisted of a chickpea, bean, or lentil stew. This was the basic (somewhat restricted) diet.

Further material remains include a few jars and metal containers. A fork that had been bent in the middle was also found; this was common practice to make it fit into a combat jacket pocket and keep it safe. Some remains of apparel were also uncovered, although these are less common as they were mainly made of cloth or leather. A piece of canvas with a brass eye has been preserved; it was probably used for covering and camouflaging the positions. Other finds include fragments of utensils and tools of daily use, such as knives and razors, as well as rubber caps from the worn soles of the soldiers' boots.

Such day-to-day objects tell us about the habits of the combatants and allow us to glimpse their daily life at this position. They also show us the harshness of war, the constant tension of combat, the scarcity of food and, on occasions, the hunger and the fear of being wounded or succumbing to illness. The material remains complement the written record that we have from the period, as do the testimonies of the witnesses who are still among us today and who keep their memories alive.

\section{Conclusion}

The Spanish Civil War is a topic that continues to attract the attention of a wide range of scholars, and that is still very present in contemporary Spanish society. In this paper, we have presented an interdisciplinary approach to the evidence from Monte Bernorio, which constituted one of the key sites in the so-called "Northern Front." The strategic position of this mounatin explains why it became a highly disputed position during two wars separated by nearly 2,000 years: the Roman conquest in the late 1st century BCE and the Spanish Civil War in 1936-37. Our archaeological work during the last few years has allowed us, together with an analysis of the existing written documentation, to reconstruct not only the "big picture" of the military events, but also many aspects of the daily life of the soldiers from both sides of the conflict. Therefore, archaeology can help provide a more "bottom-up" approach, thus connecting the "macrohistory" of the war with the "microhistory" of the combatants at a specific site. While many questions remain open, the research of the last years at Monte Bernorio is helping to recover the memory of the eventful initial months of a war that changed Spain's history.

Acknowledgments We would like to thank the Leverhulme Trust and the local and regional authorities for their support during the fieldwork campaigns at Monte Bernorio.

Open Access This article is licensed under a Creative Commons Attribution 4.0 International License, which permits use, sharing, adaptation, distribution and reproduction in any medium or format, as long as you give appropriate credit to the original author(s) and the source, provide a link to the Creative Commons licence, and indicate if changes were made. The images or other third party material in this article are included in the article's Creative Commons licence, unless indicated otherwise in a credit line to the material. If material is not included in the article's Creative Commons licence and your intended use is not permitted by statutory regulation or exceeds the permitted use, you will need to obtain permission directly from the copyright holder. To view a copy of this licence, visit http://creativecommons.org/licenses/by/4.0/. 


\section{References}

Beevor, A. (2006). The Battle for Spain: The Spanish Civil War 1936-1939. Weidenfeld and Nicolson, London.

Brown, C. J., Torres-Martínez, J. F., Fernández-Götz, M., and Martínez-Velasco, A. (2017). Fought under the Walls of Bergida: KOCOA analysis of the Roman attack on the Cantabrian oppidum of Monte Bernorio (Spain). Journal of Conflict Archaeology 12 (2): 115-138.

Fernández-Götz, M., Torres-Martínez, J. F., and Martínez-Velasco, A. (2018). The Battle at Monte Bernorio and the Augustan conquest of Cantabrian Spain. In Fernández-Götz, M. and Roymans, N. (eds.), Conflict Archaeology: Materialities of Collective Violence from Prehistory to Late Antiquity. Routledge, New York, pp. 127-140.

García Guinea, L. (2005). Diario de Guerra: Un Paréntesis de Tres Años (1936-1939). Cultura and Comunicación, Palencia.

González-Ruibal, A. (ed.) (2008). Arqueología de la Guerra Civil Española. Editorial Complutense, Madrid.

González-Ruibal, A. (2012). From the battlefield to the labour camp: archaeology of civil war and dictatorship in Spain. Antiquity 86: 456-473.

González-Ruibal, A. (2016). Volver a las Trincheras. Una Arqueología de la Guerra Civil Española. Alianza Editorial, Madrid.

González-Ruibal, A. (2020). The Archaeology of the Spanish Civil War. Routledge, London.

Graham, H. (2005). The Spanish Civil War: A Very Short Introduction. Oxford University Press, New York.

Manrique, J. M. and Molina, L. (2006). Las Armas de la Guerra Civil Española: El primer Estudio Global y Sistemático del Armamento Empleado por Ambos Combatientes. Editorial Esfera, Madrid.

Payne, S. G. (2012). The Spanish Civil War. Cambridge University Press, Cambridge.

Pérez-Juez Gil, A. and Morín de Pablos, J. (eds.) (2020). Arqueología de la Guerra Civil y la Dictadura Española: La Historia NO Escrita. BAR International Series 2965, Oxford.

Román Ibáñez, W. (2013). El Monte Bernorio en la Guerra Civil: la disputa por un enclave estratégico. Colección Historia de la Montaña Palentina 7: 87-130.

Román Ibáñez, W. (2015). Combate en la Montaña: El Frente de Palencia y Cantabria en la Guerra Civil (Julio de 1936-Febrero de 1937). Aruz Ediciones, Palencia.

Ruiz Alonso, F. (2012). Aguilar, Barruelo y Reinosa en la Guerra Civil: Ofensiva del Frente norte PalenciaSantander, 1936-1937. Editor S. A, Madrid.

Torres-Martínez, J. F., Fernández-Götz, M., Martínez-Velasco, A., Vacas, D., and Rodríguez-Millán, E. (2016). From the Bronze Age to the Roman conquest: the oppidum of Monte Bernorio (Northern Spain). Proceedings of the Prehistoric Society 82: 363-382.

Torres-Martínez, J. F. (2015). El ataque a Monte Bernorio (Villarén, Pomar de Valdivia, Palencia). In Camino, J., Peralta, E., and Torres-Martínez, J. F. (eds.), Las Guerras Astur-Cántabras. Gijón, pp. 111-129.

Valenciaga, J. L. (2007). Armas utilizadas habitualmente en los frentes de Eibar y Elgueta. La Guerra Civil en Eibar y Elgueta. Anexo VI, Eibar.

Publisher's Note Springer Nature remains neutral with regard to jurisdictional claims in published maps and institutional affiliations. 